\title{
Prospects and efficiency measurement of artificial intelligence in the management of enterprises in the energy sector in the era of Industry 4.0
}

ABSTRACT: The evolution of the economy and the formation of Industry 4.0 lead to an increase in the importance of intangible assets and the digitization of all processes at energy enterprises. This involves the use of technologies such as the Internet of Things, Big Data, predictive analytics, cloud computing, machine learning, artificial intelligence, robotics, 3D printing, augmented reality etc. Of particular interest is the use of artificial intelligence in the energy sector, which opens up such prospects as increased safety in energy generation, increased energy efficiency, and balanced energy-generation processes. The peculiarity of this particular instrument of Industry 4.0 is that it combines the processes of digitalization and intellectualization in the enterprise and forms a new part of the intellectual capital of the enterprise. The implementation of artificial intelligence in the activities of energy companies requires consideration of the features and stages of implementation. For this purpose, a conceptual model of artificial intelligence implementation at energy enterprises has been formed, which contains: the formation of the implementation strategy; the design process; operation and assessment of artificial intelligence. The introduction of artificial intelligence is a large-scale and rather costly project; therefore, it is of interest to assess the effectiveness of using artificial intelligence in the activities of energy companies. Efficiency measurement is proposed in

$\triangle$ Corresponding Author: Hanna Doroshuk; e-mail: doroshuk.anna@gmail.com

${ }^{1}$ Department of Menegement, Odessa Polytechnic State University, Ukraine; ORCID iD: 0000-0002-0340-7514; e-mail: doroshuk.anna@gmail.com

2021. The Author(s). This is an open-access article distributed under the terms of the Creative Commons Attribution-ShareAlike International License (CC BY-SA 4.0, http://creativecommons.org/licenses/by-sa/4.0/), which permits use, distribution, and reproduction in any medium, provided that the Article is properly cited. 
the following areas: assessment of economic, scientific and technical, social, marketing, resource, financial, environmental, regional, ethical and cultural effects as well as assessment of the types of risks associated with the introduction of artificial intelligence.

KEYWORDS: artificial intelligence, efficiency measurement, risks of artificial intelligence, Industry 4.0

\section{Introductoin}

The economy is evolving from agrarian to industrial, and the current stage of development is the digital economy, which is already global, with the dominance of the service sector and a significant segment of intangible services. The digital economy is being formed with the development of digital technologies, when data becomes an important asset for business, it forms new lines of business and, most importantly, other business models for existing businesses: platforms (Amazon, Alibaba, Airbnb, Booking, Uber); sharing business models (BlaBlaCar); business models based on user data (Facebook, Google); software-as-a-service (Google Docs); infrastructure-as-a-service. The next stage of development will be a virtual economy, in which the main benefit and the subject of exchange will be data, upon which, the ability to create other benefits depends.

The gradual evolution of the economy is influenced by many environmental factors, one of the most driving is the Covid-19 pandemic, which can be considered the beginning of the era of singularity, which can be defined as being the unpredictability of events in the world (Berger 2013). The global crisis which mankind enters into during a pandemic, like any crisis, means the collapse of the existing state, but it also provides new opportunities for development and forms megatrends that shape the economy of the future: the internet of things; improving artificial intelligence systems, which in the next five years will turn into a $\$ 49$ billion industry; welfare economics; a carbon neutral economy supported by investments in renewable energy sources; development in the fields of biomaterials, crop production and synthetic biology; experience economy.

The transformation of the existing economies and the emergence of new economies will lead to the emergence of a new mental model and a new paradigm of management (Bakke 2005; Doroshuk 2019; Laloux 2014). The new management paradigm will narrow the planning horizon, self-governing teams will change the administrative and team style of work, the speed of order fulfillment will be appreciated, and the principle of "the customer is always right" will be abandoned in favor of finding a potential customer.

In addition, the modern economy is becoming increasingly intellectualizedand knowledge -based, which is associated with research, constant generation and innovation. All this has a significant impact on enterprises and, above all, on the management systems of industrial enterprises (Borowski 2016, 2020; Kinelski 2020). 
Industry 4.0 involves the use of technologies such as the Internet of things, Big Data, predictive analytics, cloud computing, machine learning, artificial intelligence, robotics, 3D printing, augmented reality etc. Furthermore, artificial intelligence is a technology that combines the processes of digitalization and intellectualization.

Artificial intelligence of an industrial enterprise is an organized set of information technologies that can take over the individual cognitive functions of a person and act as an intelligent agent that, using a system of scientific research methods and algorithms for processing information obtained or independently created during work, perceives the environment and makes a decision according to the set management and production tasks.

This is why artificial intelligence is turning into a new object of intellectual capital and underlies the formation of intelligent industrial enterprises, their management and their production technologies which have cognitive features (Hoe 2019; Jensen 2005; Koistinen 2021; Pan 2020; Tortorella 2020).

Such a significant change in the conditions for the functioning and development of industrial enterprises in Industry 4.0 and the complexity of predicting the further course of events lead to the need to search for a modern methodology for the implementation and assessment of artificial intelligence in the activities of industrial enterprises. To achieve this, the following tasks are addressed in the article:

$\downarrow$ The perspectives of using artificial intelligence in energy enterprises are analyzed.

$\checkmark$ A conceptual model is developed for the introduction of artificial intelligence on the principles of the formation of an intelligent industrial enterprise such as evolution, self-organization and learning.

$\checkmark$ Approaches to assessing the effectiveness of the implementation of artificial intelligence are proposed.

Concepts of energy management in Industry 4.0, scientific principles and methods, normative documents and the works of scientists form the theoretical and methodological basis of research.

To solve the of tasks abstract-logical analysis, decomposition methods for the formation of the conceptual model for the implementation of artificial intelligence in industrial enterprises are used. Methods for assessing artificial intelligence as part of intellectual capital, performance measurement methods, and classification-analytical analysis of the risks of using artificial intelligence deployments is employed.

\section{Prospects of artificial intelligence in the management of enterprises of the energy sector}

Those enterprises that already exist and those that will be created include the development of a new mental model and a new paradigm of management, which will allow them to function 
successfully in a singular environment, or transcendence, which may become a reality as early as 2030-2035 (Blommaert 2017). Acceleration, deceleration or turbulence of the states of the external environment will lead to the replacement of a linear development model with an exponential version. In the new management paradigm, the planning horizon will be narrowed, the administrative-command style of work will be changed by self-managing teams, the speed of order fulfillment will be appreciated, and the principle of "the client is always right" will be abandoned in favor of finding a potential client.

The modern theory of endogenous growth, formulated in 1990 by P. Romer (Nobel Prize in Economics 2018), argues that growth is possible with investments in human capital, innovation and knowledge, in other words, in the internal environment of the organization, although the external environment also has a positive effect value (Romer 994). All this allows us to conclude that the organizational phenomenon that determines the development of enterprises in the context of the intellectualization of the economy, Industry 4.0 and their transition to an intellectual type is intelligence, which can be defined as a "collective brain", one of the new forms of which is artificial intelligence.

The complexity of industrial reform is determined by the turbulence of changes in the global economy, a significant increase in information and the emergence of new challenges of the information society and Industry 4.0. This is why the use of digital technologies and artificial intelligence is an integral part of the development of industry as a high-tech industry.

The change in the form of civilization, also called the "third wave", directly takes place when information and knowledge become the dominant development resource (Toffler 1984). However, traditional computer technologies themselves in the previous decade have faced an avalanche-like growth of information that they are unable to process. Problems and tasks that operate with fuzzy sets come to the fore. The need to endlessly create terabytes of software leads to the need to move to a qualitatively new information technology level, which can only be provided by artificial intelligence systems.

According to expert estimates, up to $80 \%$ of information owned by companies is not structured, and data systematization is possible due to intelligent solutions. Less than $5 \%$ of professions can be fully automated today, according to the McKinsey Global Institute. By 2030, 57 specialties will disappear, jobs will replace $20 \%$ of professions. In the 2040 s, artificial intelligence systems in terms of computational capabilities will equal and even surpass the human brain. The use of artificial intelligence in industry is one of the areas of work for the digitalization of an enterprise. This technology helps to prevent equipment failures, reduce maintenance costs, and avoid business disruption due to failures. The concept of artificial intelligence was introduced by Dartmouth College professor John McCarthy in 1956, he investigated how you can teach a machine, like a child, the use of language, self-improvement by trial and error, and an abstract concept.

Artificial intelligence of an enterprise is an organized set of information technologies that can take on individual cognitive functions of a person and act as an intelligent agent that, using a system of scientific research methods and algorithms for processing information obtained or independently created during work, perceives the environment and makes a decision in accordance 
with set managerial and production tasks (Jackson 2019; Jones 2017; McKinsey 2017; Piano 2020). Artificial intelligence can be general (performs many functions) and narrow (performs one function); weak (programmed to perform one task), strong (similar to human intelligence, can perform any mental tasks that humans can do), super artificial intelligence (any intelligence that significantly exceeds human cognitive abilities).

An important indicator of the development of artificial intelligence in business and industry is the publication activity on the topic. Our own research according to Google Academy data shows significant growth from 63,700 in 2000 up to 233,000 publications in English in 2019, in other words, a 3.7-times increase. During the study period, publications in Polish, Russian, and Ukrainian were significantly fewer, but the increase is 10,25 and 36 times, respectively.

The use of artificial intelligence in the energy sector is one of the areas of work for the digitalization of an enterprise. This technology helps prevent equipment failures, reduce maintenance costs, and avoid business disruption due to disruptions. The main tasks of artificial intelligence in nuclear power are:

$\checkmark$ ensuring the safety of reactors through a system for detecting cracks and defects in reactors using neural networks that analyze video images from special cameras; formation of recommendations for the implementation of repairs and lists of defects; identification of "abnormal events" in production processes that are invisible to employees; predicting parameters that are difficult to calculate in real time (for example, health index of installations and efficiency; predicting equipment malfunction; forming a single operator-crawler complex (analysis of voice commands; analysis of images from a video recorder, analysis of databases of parameters; modifications and defects equipment; acoustic analysis of the environment);

$\downarrow$ NPP status monitoring and analysis of the data flow coming from sensors, monitoring and control systems, comparing them with the reference data of the information base using data fusion algorithms and stating the presence or absence of a problem; in the same manner, analyzing the state of the environment in the area of the nuclear power plant by monitoring pollution and emissions;

$\downarrow$ managing catastrophic risks, including the risks of uncontrolled reactions and attacks on nuclear power plants, to prevent them or reduce the hazard level;

$\downarrow$ the creation of digital models of nuclear power plants in accordance with the IAEA requirements, which will allow accumulating information on all technical, technological and operational processes and control them in real time, ensuring the safety of the nuclear power plant;

$\checkmark$ tasks of cybersecurity;

$\downarrow$ forecasting tasks (using artificial intelligence algorithms to predict energy production and consumption, optimize equipment operation, etc.);

$\downarrow$ energy efficiency objectives (in terms of monitoring energy consumption data);

$\checkmark$ intellectualization tasks (processing the results of monitoring the state of energy facilities, algorithms for the functioning of a "smart" house, load control, etc.) (Bostrom 2014; Von Ketelhod 2008; Sozontov et al. 2019).

The active use of artificial intelligence systems in the wind energy industry illustrates the prospects for using artificial intelligence in forecasting. For example, the energy provider Xcel 
(USA, Colorado) uses satellite observations in the areas where wind farms are located to optimize the operation of wind farms. The full-scale use of artificial intelligence algorithms in the US wind farm would have increased their generation in 2017 by 12 billion $\mathrm{kWh}$ and the share of wind energy in the total balance by $6.3 \%$.

At General Motors, artificial intelligence is used to improve the efficiency of wind turbines by $5 \%$, while reducing maintenance costs by $20 \%$. IBM is partnering with the US Department of Energy to implement the SunShot initiative, a self-paced program that reliably predicts the generation of renewable sources (solar, wind, and hydro). For forecasting, retrospective information is used along with real-time weather monitoring.

The artificial intelligence system used in the operation of electrical networks (Schleswig-Holstein Netz AG, Germany, Schleswig-Holstein) is used to determine the locations of suspected damage based on information about the service life of electrical network components and repairs carried out as well as information on the load and weather conditions. The neural network of the American company AirFusion makes it possible to solve the problems of the possible detection of damage to high-voltage power lines and wind turbines. Furthermore, the self-learning system works on the basis of pattern recognition, for which thousands of images of wind-turbine damage from lightning strikes, coating erosion, etc. are loaded into the system (Sozontov et al. 2019).

Practice confirms the efficiency of using resources and saving them. At General Motors, the use of artificial intelligence has increased the efficiency of wind turbines by $5 \%$, while the cost of maintenance has been reduced by $20 \%$. Google, by implementing the solution of its subsidiary DeepMind, reduced the total energy consumption in its total data center by $15 \%$, in the coming years, cost savings could amount to several hundred million dollars.

\section{Conceptual foundations for the introduction of artificial intelligence in energy enterprises}

The main differences between artificial intelligence and other digital technologies is its transformation into an intelligent agent that can recognize objects in the environment and make decisions. It is this feature that requires the formation of conceptual foundations for the introduction of artificial intelligence in the enterprise (Fig. 1), which contain the formation of a strategy for the introduction of artificial intelligence, the design of artificial intelligence, the exploitation of artificial intelligence and the assessment of artificial intelligence.

Choosing a corporate strategy for the introduction of artificial intelligence enables the enterprise to analyze data at levels beyond human comprehension and act on each new set of data that is received, which allows for an individual approach to working with customers, developing products and services based on their needs, identifying opportunities, growing faster and more accurately than ever before, and driving operational and business model changes. 


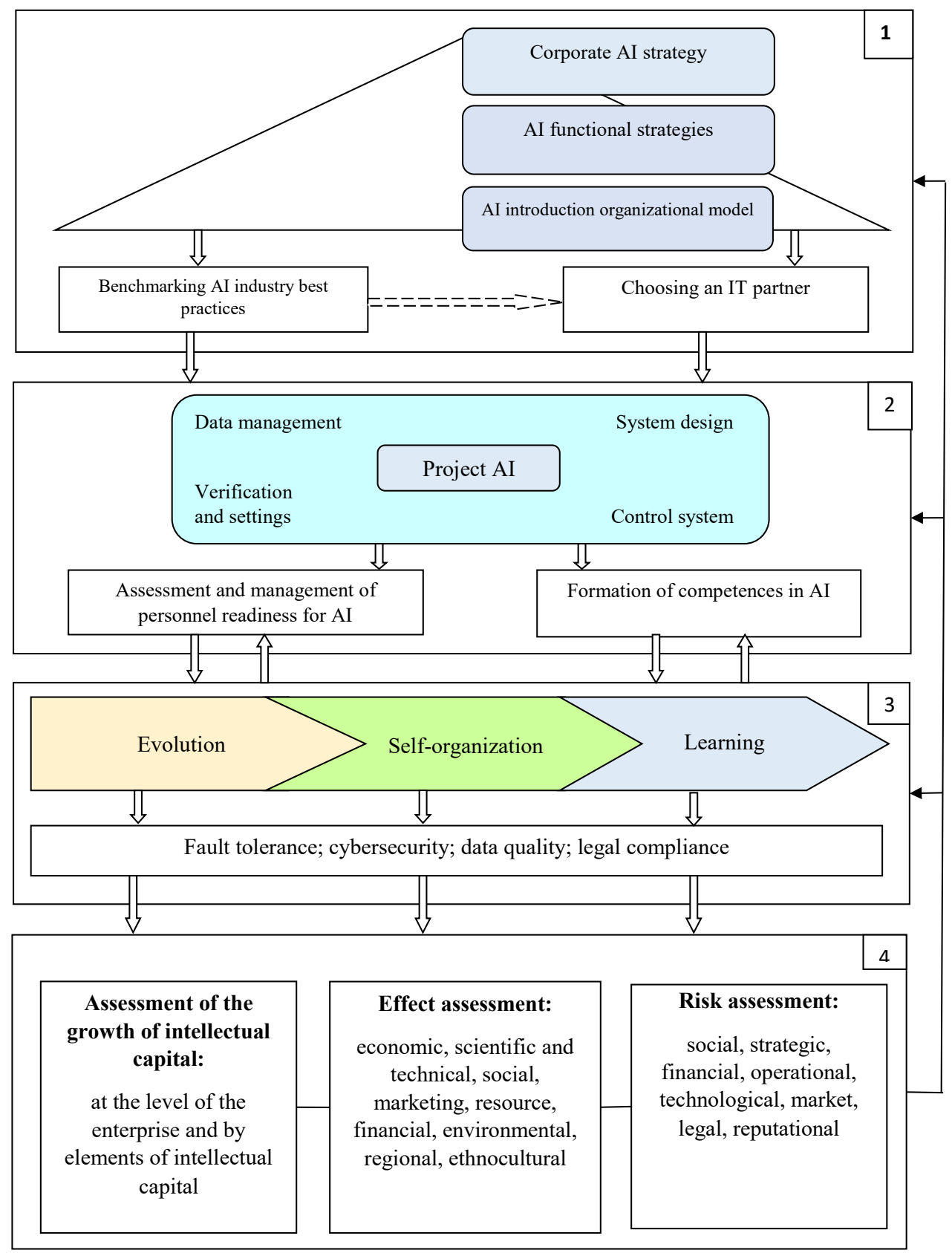

Fig. 1. Conceptual model for the artificial intelligence introduction at an energy enterprise 1 - formation of an AI (artificial intelligence) introduction strategy; 2 - AI design; 3 - AI exploitation; $4-\mathrm{AI}$ assessment

Source: author's own study

Rys. 1. Model koncepcyjny wprowadzenia sztucznej inteligencji w przedsiębiorstwie energetycznym 
It is advisable to define and systematize functional strategies for artificial intelligence introduction into the activities of enterprises in the context of the following special management functions: personnel management, production management, risk management, financial management, innovation management, etc. This defining and systematizing is advisable since it allows us to consider the impact of artificial intelligence technologies on all activities of enterprises and especially on the organizational and economic parts of it.

Funding for new projects is mainly carried out at the enterprise's own expense or withloans. Therefore, in order to improve the situation with regard to attracting additional foreign investment, it is advisable to attract interested European and Chinese investors through:

$\checkmark$ own financing at the expense of profit (restriction in the implementation of investment programs);

$\checkmark$ external financing through credit funds (funds of banks and financial institutions in Europe, USA) and funds of international partners (financing and scientific and technical assistance from European and Chinese investors);

$\checkmark$ blended financing - venture financing (the formation of a venture fund with the involvement of investors to finance small business startups and business growth).

The organizational model for the introduction of artificial intelligence enables the creation of an artificial intelligence technology management unit, which will include a senior management representative, data analysts, designers, business analysts, and representatives of future users.

It is advisable to identify the prospects for using artificial intelligence in an enterprise using benchmarking technology: choosing directions for organizational development using benchmarking; formation of a benchmarking team; selection of the level of changes (the object of benchmarking); development of the project making the necessary changes; search for a reference enterprise-leader and key success factors; adaptation of the benchmarking model and its implementation; assessment of ongoing changes.

The choice of an IT partner is of great importance due to the need to have experience working with just such projects. In this regard, industrial enterprises may encounter a shortage of developers, so with 500+ IT companies in Ukraine dealing with artificial intelligence, only $6 \%$ work within the industrial sector.

Designing artificial intelligence in terms of a self-learning enterprise includes: "evolution" the principles of building a neural network; "self-organization" - an algorithm for solving a problem using artificial intelligence; "learning" - methods of teaching artificial intelligence. In addition, for the design stage, questionnaires of personnel readiness for artificial intelligence and online tools for achieving digital competencies in the use of artificial intelligence can be proposed.

The readiness to implement artificial intelligence is considered as the readiness of the enterprise personnel for the changes that are caused by the work of artificial intelligence. Readiness is influenced by the following factors: understanding the importance of the problem and knowing the real situation; staff readiness for innovation (desire, experience, ability); financial capabilities of the enterprise; the level of technological equipment of the enterprise; desire and ability to use 
the borrowed competences (ideas, projects, consultations); information readiness; organizational and functional readiness (Armenakis 1993).

Questionnaires can be used to assess the readiness of the personnel to implement artificial intelligence. The readiness assessment carried out at the industrial enterprises of Ukraine, which are of considerable age, demonstrates an above average level of readiness. This indicates the interest of personnel in projects for the introduction of artificial intelligence and a direct connection between the age of industrial enterprises and their readiness to develop various forms of intelligence (Fig. 2).

The number above the bar of the chart is the readiness level on a sixty-point scale; the numbers under the bar of the diagram are the number of the investigated enterprise and its age in years.

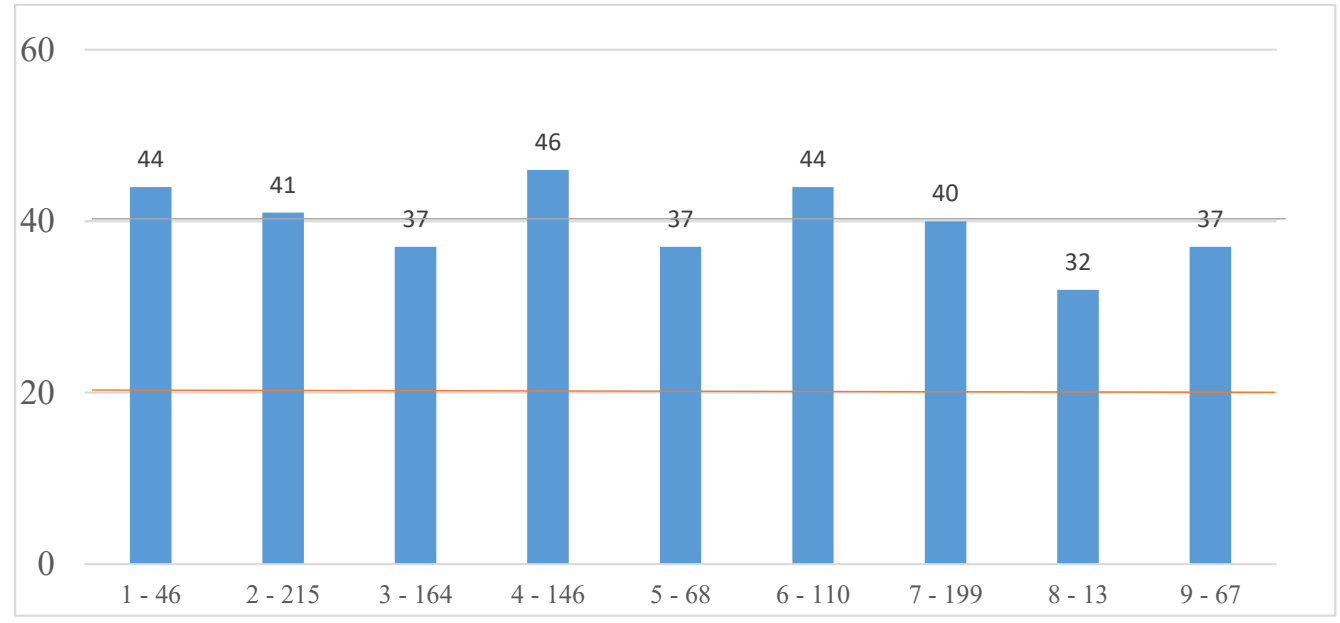

Fig. 2. Dependence of the personnel readiness level for artificial intelligence introduction and the age of an industrial enterprise Source: author's own study

Rys. 2. Zależność poziomu gotowości personelu do wprowadzenia sztucznej inteligencji od wieku przedsiębiorstwa przemysłowego

All surveyed enterprises show the level of readiness of personnel for the artificial intelligence introduction to be above average, which indicates an interest in an innovative project and the need for the introduction of digital technologies.

Artificial intelligence exploitation involves, firstly, training artificial intelligence and using the principle of self-organization in the use of this technology, and secondly, achieving resiliency indicators, cybersecurity, data quality and legal compliance.

The next section will be devoted to the assessment of artificial intelligence. 


\section{Approaches to assessing the effectiveness of the introduction of artificial intelligence into the activities of enterprises}

The assessment of the introduction of artificial intelligence into the activities of enterprises from our point of view can be carried out in three ways: a) assessment of the growth of intellectual capital; b) assessment of the economic, scientific and technical, social, marketing, resource, financial, environmental, regional and cultural effect; c) assessment of the risks of introducing artificial intelligence according to the proposed catalog of human, social, strategic, financial, operational, man-made, technological, market, legal and reputation risks.

Assessment of artificial intelligence through the growth of intellectual capital according to the initial approaches uses the integral indicator of intellectual capital and Tobin's coefficient, which is the most commonly applied in world practice (Levy 2009). These and other indicators allow us to assess the overall level of the effect of the introduction of artificial intelligence in the enterprise.

The use of a structural approach to assessing the implementation of artificial intelligence will make it possible to assess the effectiveness of the implementation of artificial intelligence for the entire enterprise and to identify the most investment-attractive projects through the use of indicators for assessing artificial intelligence as one of the elements of intellectual capital (Table 1).

Attempts to assess the effectiveness of the development and implementation of artificial intelligence raise the following issues:

$\downarrow$ Firstly, there is a significant release of the company's personnel according to the effect of the production function of Cobb-Douglas; such a release can lead to negative social consequences.

$\downarrow$ Secondly, there is a very significant payback period for such projects, especially pilot projects.

The following different types of effect and efficiency indicators of the development and implementation of artificial intelligence can be proposed for efficiency assessment and measurement:

$\checkmark$ the economic effect, which takes into account the full amount of results and costs and the level of impact of the quality types of innovative effects that are obtained from the development and implementation of artificial intelligence (project costs, tax on artificial intelligence);

$\checkmark$ the scientific and technical effect, which manifested at the stage of development of the artificial intelligence and is accompanied by the accumulation and growth of scientific, technical and technological information, namely certificates of state registration of the innovative projects; the scientific and technical potential of the developers; prospects for implementation and dissemination of proposed technical solutions; technical level of the project;

$\checkmark$ the social effect, which expresses a qualitative innovative result that takes into account the needs of man and society by improving the standard of living; improving health care; increasing the effectiveness of various social programs; developing a democratic society; improving education; meeting aesthetic needs; reducing morbidity; releasing of employee time; 
TABLE 1. Methodological tools for assessing the implementation of artificial intelligence as an element of intellectual capital by levels and methods of assessment

TABELA 1. Metodyczne narzędzia oceny implementacji sztucznej inteligencji w obszarze kapitału intelektualnego według poziomów i metod oceny

\begin{tabular}{|c|c|c|c|c|}
\hline $\begin{array}{l}\text { Level } \\
\text { of assessment }\end{array}$ & $\begin{array}{c}\text { Subject (element) } \\
\text { of assessment }\end{array}$ & $\begin{array}{c}\text { Types } \\
\text { of assessment } \\
\text { methods }\end{array}$ & Methods & $\begin{array}{l}\text { The resulting } \\
\text { |performance indicators }\end{array}$ \\
\hline \multirow[t]{3}{*}{ Enterprise level } & $\begin{array}{l}\text { business proces- } \\
\text { ses related to the } \\
\text { use of intellectual } \\
\text { resources }\end{array}$ & qualitative & $\begin{array}{l}\text { Method of balanced indicators } \\
\text { Navigator Scandia } \\
\text { The Intangible Assets } \\
\text { Monitor Sveiby } \\
\text { "Measures that Matter", } \\
\text { consulting firm Ernst \& Young } \\
\text { methodology } \\
\text { "Value Chain Scoreboard", } \\
\text { Leva's model }\end{array}$ & $\begin{array}{l}\text { the set of qualimetric } \\
\text { characteristics of busi- } \\
\text { ness process measure- } \\
\text { ment }\end{array}$ \\
\hline & \multirow[b]{2}{*}{ business value } & $\begin{array}{l}\text { quantitative } \\
\text { (market) }\end{array}$ & Market capitalization method & Tobin's coefficient \\
\hline & & $\begin{array}{l}\text { quantitative } \\
\text { (income) }\end{array}$ & $\begin{array}{c}\text { Integrated indicator } \\
\text { of intellectual capital } \\
\text { UNIDO methodology for } \\
\text { assessing the effectiveness of } \\
\text { investments in intangible assets }\end{array}$ & $\begin{array}{c}\text { investment efficiency } \\
\text { indicators (NPV, PI, } \\
\text { PP, IRR) }\end{array}$ \\
\hline \multirow{6}{*}{$\begin{array}{l}\text { The level } \\
\text { of the element } \\
\text { of intellectual } \\
\text { capital }\end{array}$} & \multirow{6}{*}{$\begin{array}{l}\text { intellectual } \\
\text { property objects }\end{array}$} & \multirow{4}{*}{$\begin{array}{l}\text { quantitative } \\
\text { (income) }\end{array}$} & $\begin{array}{l}\text { The method of added } \\
\text { economic value }\end{array}$ & $\begin{array}{l}\text { economic Added Value } \\
\text { (EVA) }\end{array}$ \\
\hline & & & $\begin{array}{l}\text { Method of estimated value } \\
\text { of intangible assets }\end{array}$ & $\begin{array}{l}\text { calculated intangible } \\
\text { value (CIV) }\end{array}$ \\
\hline & & & $\begin{array}{l}\text { The method of intellectual } \\
\text { coefficient in value added }\end{array}$ & $\begin{array}{l}\text { value Added Intellectual } \\
\text { Coefficient } \\
\text { (VAIC) }\end{array}$ \\
\hline & & & $\begin{array}{l}\text { The method of income on } \\
\text { the capital of knowledge }\end{array}$ & $\begin{array}{c}\text { income On Knowledge } \\
\text { Capital (KCI) }\end{array}$ \\
\hline & & $\begin{array}{l}\text { quantitative } \\
\text { (costly) }\end{array}$ & Direct calculation method & $\begin{array}{l}\text { the amount of actual } \\
\text { costs of creating an } \\
\text { intellectual asset }\end{array}$ \\
\hline & & others & $\begin{array}{l}\text { Index method } \\
\text { Real options method }\end{array}$ & mixed assessment \\
\hline
\end{tabular}

Source: author's own study based on Behrens 1978; Edvinsson 1997; Firer 2003; Levy 2009; Nazari 2007.

the marketing effect, which reflects the optimization and cost savings by reducing the time of entry of the product into the market (for example, reducing costs and increasing profits through the use of a new model of the electricity market); 
$\checkmark$ the resource effect, which is characterized as the interconnection of the needs of innovative activities for the consumption of various types of resources at the enterprise (the project schedule; the availability of appropriate land plots; premises and infrastructure of the facility; the technological level of the existing and planned production; provision of production with qualified personnel - measures are provided to improve their qualifications; provision of project implementation with raw materials, the required equipment and labor resources, compliance of the draft energy saving strategy, implementation of energy saving measures);

$\checkmark$ the financial effect, which acts as a generalizing indicator of the level and type of impact of innovation on changes in the financial condition and performance of enterprises (full cost of the project; sources of financing, the ratio between the level of own and borrowed funds; financial condition of a business entity and the availability of own funds are integral indicators of the economic efficiency of projects (net present value, profitability index, internal rate of return, payback period; budget efficiency of the project, financial risks and sensitivity of the project to the most influential factors; guarantees of refund and terms of their provision);

$\checkmark$ the environmental effect, which manifests itself in the growth of the environmental friendliness of the products; reduction of emissions of harmful substances into the atmosphere, soil and water; optimizing the use of resources and reducing production waste (the impact of production processes involved in the implementation of the project on the environment; safety);

$\checkmark$ the regional effect is expressed in the role in the development of the region due to the increase in the number of jobs, better provision of goods and services, development of regional infrastructure, provision of the region with the necessary resources (compliance of the project with the needs of the market; market capacity and trends of its development; competitiveness of products in terms of price and quality - marketing activities are provided, the impact on the level of employment);

$\checkmark$ the ethnic and cultural effect, which is reflected as an effective factor of entering a new post-industrial era of human development and the ability of the state and society to adequately respond and adapt to new, increasingly complex requirements and challenges caused by it (safety culture index, production culture index, culture index management; ethical issues of implementation).

The study of the risks of the introduction of artificial intelligence allows us to propose the following classification as a catalog of risks:

$\checkmark$ personnel risks - lack of specialists; lack of motivation; lack of competencies required for development; lack of managerial competencies required to manage the use of artificial intelligence; staff resistance due to potential staffing cuts;

$\checkmark$ social risks - social tension; unresolved ethical issues; digital inequality;

$\checkmark$ strategic risks - duration of the development and implementation process; lack of standards for the development and implementation of artificial intelligence; change of strategy of the industrial enterprise; complex coordination process before development and implementation (Cheatham 2019); 
$\checkmark$ financial risks - significant cost of the development project; difficulties in attracting additional funding for development; falling national currency exchange rate; significant inflation; reduced profits due to reduced demand for products;

$\checkmark$ operational risks - management resistance in the transition to management using artificial intelligence; over-regulation of technological and managerial processes; lack of well-established communication between developers in the field of artificial intelligence;

$\checkmark$ technological risks - unforeseen emergencies; cybersecurity; technology in the early stages of testing and the final characteristics are not fully understood; loss of value of technology with the advent of new versions; safety violations;

$\checkmark$ market risks - the emergence of a cheaper analogue on the market; significant competition from foreign developers; significant influence of large companies/monopolists;

$\checkmark$ legal risks - lack of necessary certificates, licenses and permits; lack of regulatory framework; conflict of interests of development project participants;

$\checkmark$ reputational risks - loss of the company's image; loss of customer trust due to artificial intelligence errors; distrust of enterprises that use artificial intelligence.

The issue of assessing the introduction of artificial intelligence into the activities of enterprises remains controversial and is not always fully determined because there is still insufficient experience in the implementation of artificial intelligence or its clearly defined results; furthermore, the use of different types of assessment methods (quantitative, qualitative and others) requires different levels of access to the initial information in the assessment. This, in turn, requires further research regarding the formation of a methodology for assessing artificial intelligence at an enterprise.

\section{Conclusions}

One of the UN Sustainable Development Goals, "Affordable and clean energy", stipulates the need for the continuous development of energy companies and makes them active participants in the formation of Industry 4.0 (Doroshuk 2020). Digitalization and intellectualization in the introduction of artificial intelligence into the activities of energy companies has a number of features that are taken into account when forming a conceptual model of implementation based on the principles of evolution, self-organization and training.

Artificial intelligence is a long-term and rather costly project, which does not always quickly demonstrate economic efficiency; however, it serves to form an intelligent industrial enterprise, and therefore gives not only an economic effect, but also other effects which are often not predicted at the beginning of the project.

Methodological approaches to assessing the effectiveness of the implementation of artificial intelligence have not yet been sufficiently studied and formed, which is also due to the lack of experience in working with real artificial intelligence projects. The approaches proposed in the 
article for assessing artificial intelligence in a company reflect various aspects of its impact on the company's activities. The assessment of artificial intelligence as a part of an intangible asset reflects its contribution to the formation of the assets of an intellectual enterprise, the formation of which it contributes to. An attempt to classify the types of effect and their effectiveness gives an idea of the various forms of the manifestation of the economic benefit from the introduction of artificial intelligence that are not so obvious at first glance. This direction requires further refinement to the level of indicators and methods of their calculation. Using these indicators in practice will provide an opportunity to study the benefits of intelligent industrial enterprises.

The risk assessment of the introduction of artificial intelligence is justified from the point of view that artificial intelligence is most often associated with social risks (as the most common are the reduction of jobs and the complexity of interaction under the conditions of the use of new technologies) and man-made risks (associated with the peculiarities of the interaction of artificial intelligence with production processes). The conducted studies show an exaggerated importance of these types of risks, while legal risks are currently of greater importance, which is explained by the lack of a framework for regulating the use of artificial intelligence.

Industry 4.0 and the digitalization and intellectualization of the economy are in many ways changing the paradigm of governance and shaping smart industrial enterprises, which in the energy sector, provides access to affordable, reliable, sustainable and modern energy sources for all.

The research was supported by the Ministry of Education and Science of Ukraine "Organizational development strategic orientations for business entities of the real sector of the national economy" (0119U000511). This paper also contains the results of joint research of DP NNEGC Energoatom and Odessa Polytechnic State University.

\section{References}

Armenakis et al. 1993 - Armenakis, A.A., Harris, S.G. and Mossholder, K.W. 1993. Creating Readiness for Organizational Change. Human Relations 46, pp. 681-703.

Artificial intelligence the next digital frontier? McKinsey Global Institute. July 2017. 80 p. [Online] https:// www.mckinsey.com/ /media/mckinsey/industries/advanced\%20electronics/our\%20insights/how\%20 artificial $\% 20$ intelligence $\% 20$ can $\% 20$ deliver $\% 20$ real $\% 20$ value $\% 20$ to $\% 20$ companies/mgi-artificial-intelligence-discussion-paper.ashx [Accessed: 2021-07-15].

BAKKE, D. 2005. Joy a work: A Revolutionary Approach to Fun on the Job. Seattle: PVG, 314 pp.

BEHRENS, W. and HAWRANEK, P.M. 1978. Manual for the preparation of industrial feasibility studies. NY: Unated Nations, $404 \mathrm{pp}$.

Berger, R. 2013. How to Survive in the VUCA World. Hamburg: Roland Berger, 245 pp.

Blommaert, T. and Broek, S. 2017. Management in Singularity: From linear to exponential management. Vakmedianet; 1 edition, 172 pp.

Borowski, P.F. 2016. Development strategies for electric utilities. Acta Energetica 4, pp. 16-21.

Borowski, P. 2021. Innovative Processes in Managing an Enterprise from the Energy and Food Sector in the Era of Industry 4.0. Processes 9(2), 381, DOI: 10.3390/pr9020381.

Bostrom, N. 2014. Superintelligence: Paths, Dangers, Strategies. Oxford University Press, 352 pp. 
Cheatham et al. 2019 - Cheatham, B., Javanmardian, K. and Samandari, H. 2019. Confronting the risks of artificial intelligence. [Online] https://www.mckinsey.com/business-functions/mckinsey-analytics/ our-insights/confronting-the-risks-of-artificial-intelligence [Accessed: 2021-07-15].

Doroshuк, H. 2019. Organizational development: theory, methodology, practice (Організаиійний розвиток: теорія, методологія, практика). Odesa: Osvita Ukrainy, 368 pp. (in Ukrainian).

Doroshuk, H. 2020. Reform of the electricity sector in Ukraine - liberalization of the market and corporatization of companies. Polityka Energetyczna - Energy Policy Journal 23(4), pp. 105-122. [Online] https://epj.min-pan.krakow.pl/Reform-of-the-electricity-sector-in-Ukraine-liberalization-of-the-market-and-corporatization, 127664,0,2.html/ [Accessed: 2021-07-15].

Edvinsson, L. and Malone, M. 1997. Intellectual Capital: Realizing your Company's True Value by Finding its Hidden Brainpower. New York, NY: Harper Collins.

FirER, S. and WiLliams, S.M. 2003. Intellectual capital and traditional measures of corporate performance. Journal of Intellectual Capital 4(3) , pp. 348-360, DOI: 10.1108/14691930310487806.

HoE, S.L. 2019. The topicality of the learning organization: Is the concept still relevant today? [In:] The Oxford Handbook of the Learning Organization, Oxford University Press: Oxford, UK, pp. 18-32.

JACKSON, P.C. Jr. 2019. Introduction to Artificial Intelligence. New York: Dover Publication Inc., 170 pp.

JENSEN, P.E. 2005. A contextual theory of learning and the learning organization. Knowledge Process Management 12, pp. 53-64, DOI: 10.1002/kpm.217.

Jones, M.T. 2017. A Beginner's Guide to Artificial Intelligence, Machine Learning and Cognitive Computing. [Online] https://developer.ibm.com/articles/cc-beginner-guide-machine-learning-ai-cognitive/ [Accessed: 2021-07-15].

KINELSKI, G. 2020. The main factors of successful project management in the aspect of energy enterprises' efficiency in the digital economy environment. Polityka Energetyczna - Energy Policy Journal 23(3), pp. 5-20, DOI: 10.33223/epj/126435.

KoISTINEN, P. 2021. Toward learning organization - Practices in nuclear power plants. [In:] Human Factors in the Nuclear Industry, Elsevier BV: Amsterdam, The Netherlands, pp. 239-247.

Laloux, Fr. 2014. Reinventing Organizations: A Guide to Creating Organizations Inspired by the Next Stage of Human Consciousness. Brussels: Nelson\&Parker, 379 pp.

Levy, F. 2009. A simulated approach to valuing knowledge capital. Washington: The George Washington University, $189 \mathrm{pp}$.

NAZARI, J.A. and HERREMANS, I.M. 2007. Extending VAIC model: measuring intellectual capital components. Journal of Intellectual Capital 8(4), DOI: 10.1108/14691930710830774.

OKlander et al. 2018 - OKlander, M., OKlander, T., Yashkina, O., Pedko, I. and Chaikovska, M. 2018. Analysis of technological innovations in digital marketing. Eastern-European Journal of Enterprise Technologies 5/3 (95), pp. 80-91, DOI: 10.1088/1755-1315/440/2/022026.

PAN et al. 2020 - PAN, T., Hu, T. and GENG, J. 2020. View learning organization in a situational perspective. IOP Conference Series: Earth and Environmental Science 440 pp.

PIANO, S.L. 2020. Ethical principles in machine learning and artificial intelligence: Cases from the field and possible ways forward. Humanities and Social Science Communication 7, DOI: 10.1057/s41599020-0501-9.

Romer, P.M. 1994. The Origins of Endogenous Growth. The Journal of Economic Perspectives 8(1), pp. 3-22.

Sozontov et al. 2019 - Sozontov, A., Ivanova, M. and Gibadullin, A. 2019. Implementation of artificial intelligence in the electric power industry. [In:] E3S Web of Conferences 114, DOI: 10.1051/ e3sconf/201911401009. EDP Sciences.

Toffler, A. 1984. The Third Wave. NY: Bantam, 560 pp.

Tortorella et al. 2020 - Tortorella, G.L., Vergara, A.M.C., Garza-Reyes, J.A. and Sawhney, R. 2020. Organizational learning paths based upon Industry 4.0 adoption: An empirical study with Brazi- 
lian manufacturers. International Journal of Production Economics 219, pp. 284-294, DOI: 10.1016/j. ijpe.2019.06.023.

Von Ketelhod, Wöcke, A. 2008. The impact of electricity crises on the consumption behaviour of small and medium enterprises. Journal of Energy in Southern Africa 19(1), pp. 4-12.

\section{Perspektywy i pomiar efektywności sztucznej inteligencji w zarządzaniu przedsiębiorstw sektora energetycznego w dobie Przemysłu 4.0}

\section{Streszczenie}

Ewolucja gospodarki i powstanie Przemysłu 4.0 prowadzą do wzrostu znaczenia wartości niematerialnych i cyfryzacji wszystkich procesów w przedsiębiorstwach energetycznych. Wiąże się to z wykorzystaniem technologii takich jak Internet Rzeczy, Big Data, analityka predykcyjna, przetwarzanie w chmurze, uczenie maszynowe, sztuczna inteligencja, robotyka, druk 3D, rozszerzona rzeczywistość itp. Szczególnie interesujące jest wykorzystanie sztucznej inteligencji w energetyce, co otwiera takie perspektywy jak zwiększenie bezpieczeństwa wytwarzania energii, wzrost efektywności energetycznej oraz zbilansowane procesy wytwarzania energii. Specyfiką tego konkretnego instrumentu Przemysłu 4.0 jest to, że łączy procesy cyfryzacji i intelektualizacji w przedsiębiorstwie i stanowi nową część kapitału intelektualnego przedsiębiorstwa. Wdrożenie sztucznej inteligencji w działalności przedsiębiorstw energetycznych wymaga uwzględnienia ich specyfiki oraz etapowego wdrożenia. W tym celu stworzono koncepcyjny model wdrożenia sztucznej inteligencji $\mathrm{w}$ przedsiębiorstwach energetycznych, który zawiera: tworzenie strategii wdrożenia; projektowanie; działanie i ocenę sztucznej inteligencji. Wprowadzenie sztucznej inteligencji to projekt o dużej skali i dość kosztowny, dlatego warto ocenić efektywność jego wykorzystania w działalności firm energetycznych. Zaproponowano pomiar efektywności w następujących obszarach: ocena skutków ekonomicznych, naukowo-technicznych, społecznych, marketingowych, zasobowych, finansowych, środowiskowych, regionalnych, etycznych i kulturowych, a także ocenę rodzajów zagrożeń związanych $\mathrm{z}$ wprowadzeniem sztucznej inteligencji.

SŁowA KLUCZOWE: sztuczna inteligencja, pomiar efektywności, zagrożenia sztucznej inteligencji, Przemysł 4.0 